\title{
塩化物飛来環境における而候性鋼のさびの保護性*
}

\author{
竹村誠洋**, 藤田 栄**, 森田健治***, 佐藤 罊', 酒井潤一十 \\ **NKK 総合材料技術研究所 \\ *.. NKK 基盤技術研究所 \\ 十鋼管計測株式会社
}

\section{Protectiveness of Rust Formed on Weathering Steel in Atmosphere Rich in Air-Born Chloride Particles*}

\author{
Masahiro Takemura**, Sakae Fujita**, Kenji Morita***, Kaoru Sato*** and Jun-ichi Sakai ${ }^{\dagger}$ \\ * Materials \& Processing Research Center, NKK Corporation \\ *** Applied Technology Research Center, NKK Corporation \\ + Kokan Keisoku K.K.
}

\begin{abstract}
The influence of the chloride deposition on the protectiveness of rust formed on weathering steel in long term exposure was examined. Specimens of weathering steel containing $\mathrm{Cu}$ and $\mathrm{P}$ were exposed to a rural environment for 41 years. After the exposure, the corrosion behavior of the weathering steel with protective rust in the laboratory corrosion tests simulating coastal environments was observed. In the test, spots of orange rust appeared on the surface of the specimens, which increased in number and size with the increase of the deposited $\mathrm{NaCl}$. Amount of dissolved ferrous ions also was enhanced when the deposited $\mathrm{NaCl}$ was over critical amount. Through EPMA inspection of the cross sections of the rust, it was confident that $\mathrm{Cl}$ ions penetrated into the rust to reach the rust/steel interface, which suggested that the dissolution of the iron occur at the same interface. From the result of X-ray diffraction analyses and polarized light microscopic observations, change in the structure of the rust was hardly seen. The protectiveness of the rust was found to have a certain limit regarding chloride deposition, although its basic structure was apparently maintained.
\end{abstract}

Key words : weathering steel, rust, atmospheric corrosion, chloride, exposure test, dry/wet cycle, ion selective property

\section{1. 緒言}

鋼構造物のメンテナンスコストミニマム化の観点か ら，近年，耐候性鋼が注目されている。耐候性鋼は，長 期間の使用により保護性が高いさびが生成し, 腐食が抑 制されるという特徵をもつ。しかし， $\mathrm{Cu}, \mathrm{Cr}$ を主たる 添加元素とする SMA（JIS G 3114 ：溶接構造用耐候性 熱間圧延鋼材）など, 従来の耐候性鋼の場合，海岸付近 または凍結防止斉を散布する地域など, 飛来塩分量が多 い環境では，うろこ状さびが生成したり，さびが層状制 離を起こしたりするなど,さざの保護性が不十分であ り，腐食速度が低減しにくいことが知られている゙。一 方，良好な環境に長期間暴露されて安定化した耐候性鋼 であっても，塩化物が多い環境にさらされるとさびの保 護性が損なわれ，腐食が再活性化することが報告されて (るる2).3).

耐候性鋼の大気腐食には, 塩化物イオンなど, 腐食性 アニオンのさび中の透過挙動が大きく影響していると考 えられる.さびの防食作用を検討すべく，オキシ水酸化 鉄のイオン選択透過性が調へられている(1) 10). しかし,

*第 46 回材料と環境討論会（福岡, 1999 年) で発表

** ₹ 721-8510 福山市筒管町 1 番地 (1, Kokan-cho, Fukuyama, Hiroshima, 721-8510 Japan)

・.・ $\mathbf{T}$ 210-0855 川崎市川崎区南渡田町 1-1 (1-1, Minamiwataridacho, Kawasaki-ku, Kawasaki, Kanagawa, 210-0855 Japan)

十 7 210-0855 川崎市川崎区南渡田町 1-1 (1-1, Minamiwatarida. cho, Kawasaki-ku, Kawasaki, Kanagawa, 210-0855 Japan)
自然環境に長期間暴露されて生成した耐候性鋼のさびに おける塩化物イオン透過のメカニズムは，まだ明らかに されていない.

本研究では, 田園地带において 41 年間暴露されて安 定化した耐候性鋼を用い'11，塩化物に対するさびの保護 性および腐食が再活性化する過程を調へ, そのメカニス ムを検討した。

\section{2. 実 験 方 法}

\section{1 供試材および暴露試験によるさびの生成}

供試材は実験室溶解により作製された $\mathrm{Cu}-\mathrm{P}$ 添加鎆で ある.その組成を Table 1 に示す。供試材を $100 \mathrm{~mm} \times$ $150 \mathrm{~mm} \times 5 \mathrm{~mm}$ の試験片に加工し, 田園地帯である川 崎市中原区において南向き $30^{\circ} に 41$ 年間暴露した ${ }^{11}$.

暴露開始から 12 年後までは板厚減少量を測定した。 $10 \%$ クン酸二アンモニウム水溶液を用いて暴露試験片 を脱錆し, 重量減少から板厚減少量を算出した。暴露面 は試験片全面であり, 得られた値は片面板厚減少量の平 均値である。

\section{2 乾湿繰り返し試験 \\ 41 年間暴蕗した試験片に対して, 実験室において海}

Table 1 Chemical composition of weathering steel exposed to rural environment for 41 years (wt\%).

\begin{tabular}{|c|c|c|c|c|c|}
\hline $\mathrm{C}$ & $\mathrm{Si}$ & $\mathrm{Mn}_{\mathrm{n}}$ & $\mathrm{P}$ & $\mathrm{S}$ & $\mathrm{Cu}$ \\
\hline 0.04 & 0.16 & $\mathbf{0 . 4 5}$ & 0.163 & 0.018 & 0.42 \\
\hline
\end{tabular}




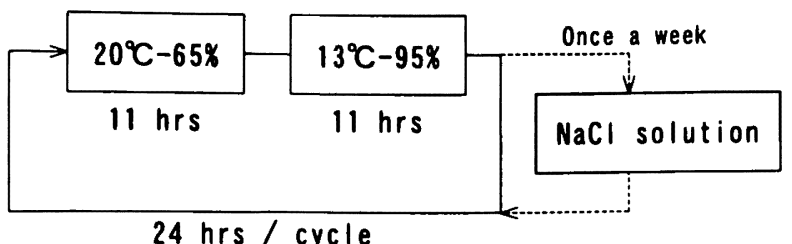

(a) Dry/wet cycle

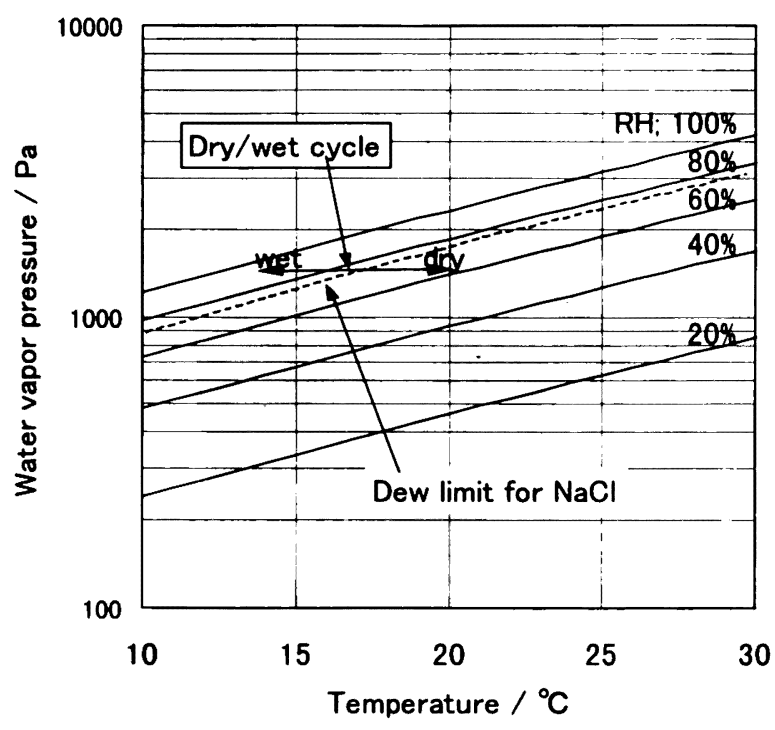

(b) Relationship between water vapor pressure and temperature

Fig. 1 Corrosion test simulating coastal environment.

岸付近の腐食環境を模擬した腐食試験を行った。その手 順を以下に示す.

41 年間暴露した試験片を $30 \mathrm{~mm} \times 40 \mathrm{~mm}$ の大きさに 乾式切断し，暴露試験時の対空面（上面）以外の面をす へてタールエポキシによりシールし，試験片とした，試 験片表面を軽く純水で洗浄した後, さび露出面全体にメ スピペットを用いて試験開始時と 1 週間後に $\mathrm{NaCl}$ 水溶 液を滴下した。この際, 試験片露出面積 $1 \mathrm{~cm}^{2}$ あたりの $\mathrm{NaCl}$ 水溶液滴下量を $40 \mu \mathrm{L}$ 一定とし，水溶液の濃度に より $\mathrm{NaCl}$ 付着量を制御した. $\mathrm{NaCl}$ 水溶液の濃度は $0.03,0.12,0.48$ wt\%であり，これらを付着 $\mathrm{NaCl}$ 量 に換算すると $0.017,0.069,0.274 \mathrm{~g} \cdot \mathrm{m}^{-2} \cdot \mathrm{day}^{-1}$ とな る. $\mathrm{NaCl}$ 水溶液を付着後, 恒温恒湿槽 (ADVANTEC 製 AGX-325）に入れて Fig. 1(a)に示す乾湿サイクルを 与えた。この乾湿サイクルは Fig. 1(b)に示すように, 露点一定で乾燥-結露を繰り返すものであり，日本の標 準的な温度一湿度変化の特徵を模擬した ${ }^{12), 13)}$.

\section{3 湿潤試験}

2.2 で述べた乾湿繰り返し試験では, 溶出した $\mathrm{Fe}^{2+}$ がさらに酸化され，さびとして沈殿しやすいことから， 以下に示す湿潤環境における腐食試験を行い, $\mathrm{Fe}^{2+}$ の 定量を試みた。

供試材を約 $25 \mathrm{~mm} \times 25 \mathrm{~mm}$ に切断し， 2.2 と同様に 試験片の暴露試験時の対空面以外をシール処理し, $\mathrm{NaCl}$ をさび露出面に付着させた．付着 $\mathrm{NaCl}$ 量は
0 4.0 g $\cdot \mathrm{m}^{-2}$ である. $\mathrm{NaCl}$ 付着後, 恒温恒湿槽に入れ て $13^{\circ} \mathrm{C}-\mathrm{RH}$ 95\%に保持した. 試験時間は $1 ， 5 ， 24$ 時 間である．5 時間保持した試験片については, 純水で洗 浄して溶出した $\mathrm{Fe}^{2+}$ を補集し, その洗浄水を原子吸光 法（日立製作所製 Z-8100）により， $\mathrm{Fe}^{2+}$ を定量した。

\section{4 さびの楼造解析}

さびの構造およびさび中の $\mathrm{Cl}^{-}$透過について調へるた めに, 以下のさび断面解析を行った.

試験片の一部を，長さ $1 \mathrm{~cm}$ 以上の断面観察可能な形 状に切断し，粘性の低い常温硬化型エポキシ樹脂にて埋 め込み，研磨して断面観察用とした。研磨はさびの剥離 や傷の発生を回避するよう十分注意して行った。研磨し た試料は偏光顕微鏡（カールツァイス製 Axiotron） を用いてさび中の偏光層, 消光層の分布を観察・写真撮 影した。その後, 偏光影微鏡写真撮影と同一視野を, 電 子線マイクロアナライザー（日本電子製 JXA-8600 MX，以下 EPMA と記す）を用いて走査型電子顕微鏡 (以下 SEM と記す)写真撮影およびさび中 $\mathrm{Cl}$ の面分析 を行った。

また残りの切片から，カッターナイフなどを用いて一 定条件で機械的に表面のさびを剝離・粉砕してさび粉末 を採取し, $\mathrm{CaF}_{2}$ 結晶を内部標準物質とする $\mathrm{X}$ 線回折内 部標準法(理学電機製 LINT 2100)により，さび組成比 を定量した．X 線源には $\mathrm{Cr}$ 管球を用い, $40 \mathrm{kV}-50 \mathrm{~mA}$ で動作させた.また,さびと $\mathrm{CaF}_{2}$ の質量配合比は 5 ：

1 であり，定量には以下のピークを用いた。

$\alpha-\mathrm{FeOOH}$; (101) 面 $\left(2 \theta=31.6^{\circ}\right)$

$\beta-\mathrm{FeOOH}$; $(220)$ 面 $\left(2 \theta=17.6^{\circ}\right)$

$\gamma$ - $\mathrm{FeOOH}:(020)$ 面 $\left(2 \theta=21.3^{\circ}\right)$

$\mathrm{Fe}_{3} \mathrm{O}_{4}$; (220) 面 $\left(2 \theta=45.4^{\circ}\right)$

$\mathrm{CaF}_{2} ;(111)$ 面 $\left(2 \theta=42.5^{\circ}\right)$

\section{3. 結果および考察}

\section{1 暴露試験結果}

暴露試験における板厚減少量の経時変化を Fig. 2 に 示す. 12 年間のデータから外挿して 41 年後の板厚減少 量は $0.12 \mathrm{~mm}$ という小さい值が推測される. 建設省土 木研究所ら 11 の共同研究では, 耐候性鋼が無塗装で適用

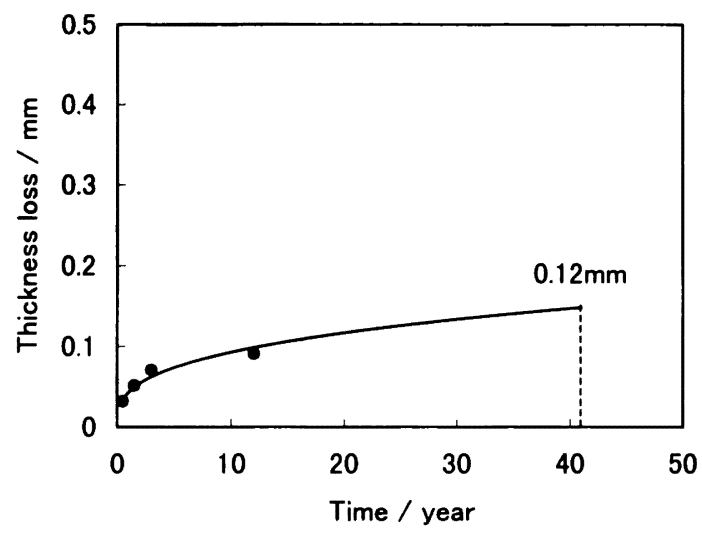

Fig. 2 Change in thickness loss of weathering steel exposed to rural environment. 


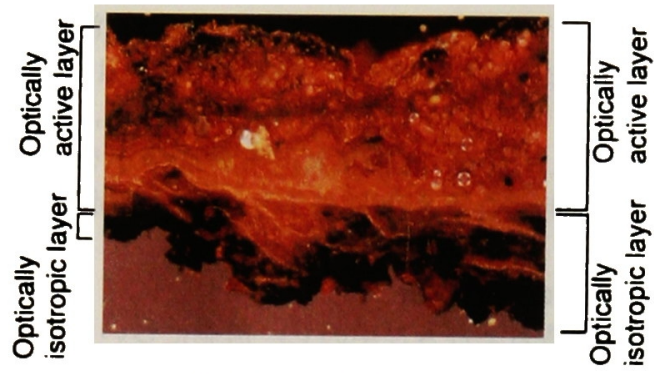

(a) Polarized light image

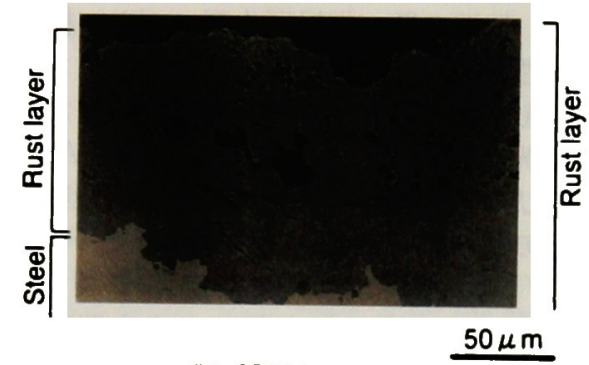

(b) SEM image

Fig. 3 Cross sections of rust formed on weathering steel exposed to rural environment for 41 years.

可能と判断できる板厚減少量を, 50 年で $0.3 \mathrm{~mm}$ 以下 としている.このことからも，供試材のさびは十分に安 定化したとみなすことができる。

\section{2 暴露試験により生成したさびの構造}

41 年暴露材のさび厚を電磁膜厚計（ケット研究所製 LE-200 C) により測定したところ，その平均値はおよ そ $120 \mu \mathrm{m}$ であった.さび表面にはくぼみが約 1.5 個・ $\mathrm{cm}^{-2}$ の密度で均一に分布しており，その深さは約 100 $\mu \mathrm{m}$, 上から見たときの平均径は約 $2 \mathrm{~mm}$ であった，暴 露試験から回収したままのさび断面の偏光顕微鏡写真を Fig. 3(a)k, SEM 写真を Fig. 3(b)に示す. Fig. 3(a) のように, さびの大気側では偏光部の割合が高かった.

一方, 鋼側, 特にさび/鋼界面では消光部の割合が高か った。消光部はFig. 3(b)に見られる㙇裂または欠陥の 少ない, 緻密化した部分とほほ一致していた ${ }^{14), 15)}$. Fig.

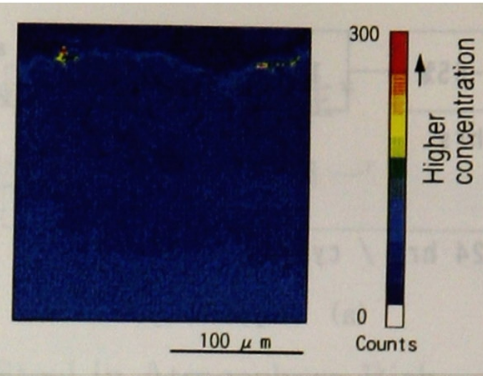

Fig. 4 EPMA analysis for cross section of rust formed on weathering steel exposed to rural environment for 41 years : distribution of $\mathrm{Cl}$.

4 に腐食試験前の EPMAによる元素分析結果を示す. $\mathrm{Cl}$ はさび中にはほとんど検出されなかった.

\section{3 乾湿繰り返し試験による新たなさびの生成}

乾湿繰り返し試験後の腐食試験片の外観を Fig.5 に示 す. 試験時間は 2 週間である. 付着 $\mathrm{NaCl}$ 量が最も多い $0.274 \mathrm{~g} \cdot \mathrm{m}^{-2} \cdot \mathrm{day}^{-1}$ の試験片には, 橙色の点状のさびが 新たに発生していることが，肉眼で確認できた，付着 $\mathrm{NaCl}$ 量が $0.069 \mathrm{~g} \cdot \mathrm{m}^{-2} \cdot \mathrm{day}^{-1}$ の試験片においても, $0.274 \mathrm{~g} \cdot \mathrm{m}^{-2} \cdot \mathrm{day}^{-1}$ に比べて発生密度は小さいが, 同様 の点状のさびが確認された。これに対して付着 $\mathrm{NaCl}$ 量 が最も少ない $0.017 \mathrm{~g} \cdot \mathrm{m}^{-2} \cdot \mathrm{day}^{-1}$ の試験片の外観は, 試験前とほとんど変わらなかった．点状さびは試験片表 面に均一に発生しており, 暴露試験により生成したさび のくほみの部分から優先的に発生することはなかった。

このような新たなさびの発生は宇佐見ら ${ }^{3)}$ も確認して いる. 彼らは 23 年暴露した耐候性鋼に対して塩水噴霧 試験を行い, 新たなさびの発生と,そのさびが $\gamma$ $\mathrm{FeOOH}$ であることを $\mathrm{X}$ 線回折により確認した。本実 験の腐食環境は海岸付近の暴露環境に近く，塩水噴霧ほ ど㺖しくないため，X線回折により同定できるほどの 量の点状のさびは発生しなかった。

\section{$3.4 \mathrm{Fe}^{2+}$ 溶出とさび/鋼界面の $\mathrm{Cl}$ 濃度の関係}

$\mathrm{NaCl}$ を付着させて $13^{\circ} \mathrm{C}-\mathrm{RH} 95 \%$ に 5 時間保持した

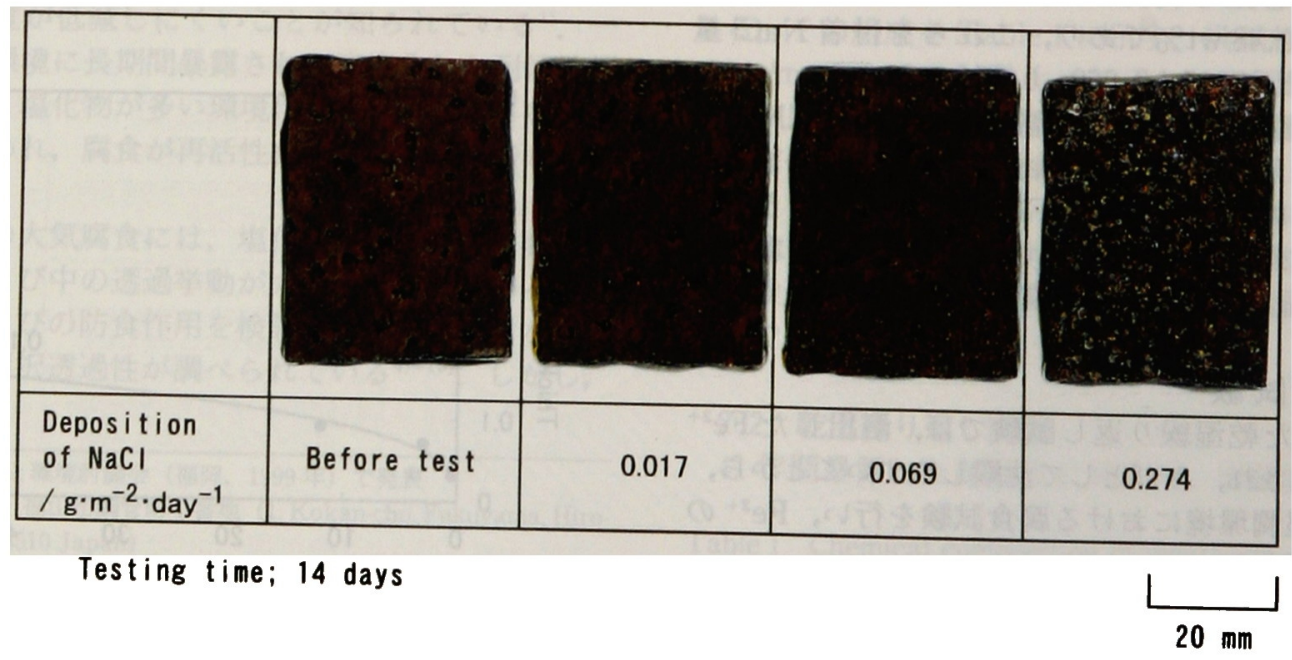

Fig. 5 Appearances of rust formed on 41 years exposed weathering steel after laboratory corrosion test. 


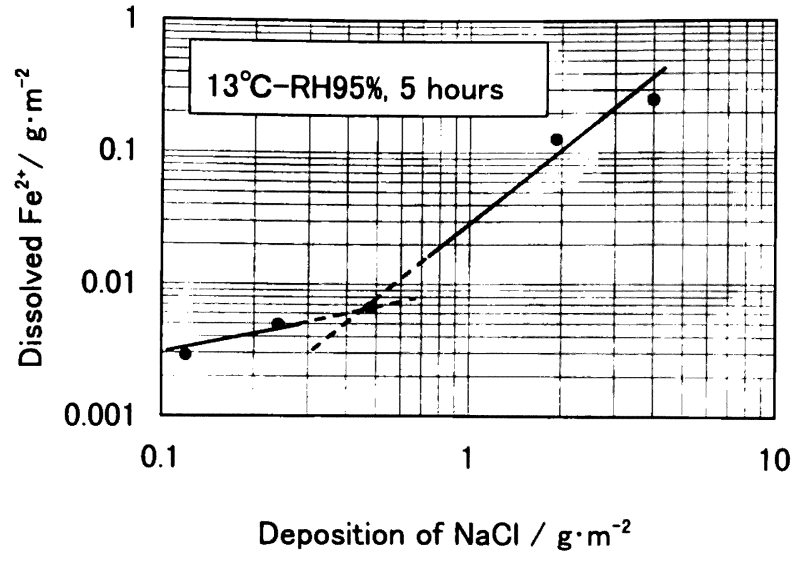

Fig. 6 Relationship between dissolved $\mathrm{Fe}^{2+}$ and deposition of $\mathrm{NaCl}$.

試験片について，溶出した $\mathrm{Fe}^{2+}$ を原子吸光法により定 量した。その結果を Fig. 6 に示す。付着 $\mathrm{NaCl}$ 量の増加 に伴い，溶出 $\mathrm{Fe}^{2+}$ 量は増加した。そ増加傾向は付着 $\mathrm{NaCl}$ 量に対して，約 $0.5 \mathrm{~g} \cdot \mathrm{m}^{-2}$ 付近を超えると急激に 増加した．安定化したさび14),15)であっても，ある一定 量以上の $\mathrm{NaCl}$ の付着に対しては保護性が不十分である ことを確認した。

耐侯性鋼表面に保護性の高いさびが生成しうる限界の 付着塩分量と，いったん生成したさびがより厳しい環境 にさらされたときの, 保護性を維持しうる限界の付着塩 化物量の関係については, 明らかにされてはいない。し かし, 本実験により得られた溶出 $\mathrm{Fe}^{2+}$ 量と付着 $\mathrm{NaCl}$ 量の関係は, 建設省土木研究所ら”が行った 41 橋にお ける暴露試験結果に見られる, SMA の腐食量が飛来塩 分量 $0.1 \mathrm{mdd}\left(\mathrm{mg} \cdot \mathrm{NaCl} \cdot \mathrm{dm}^{-2} \cdot \mathrm{day}^{-1}\right)$ を超えると急 激に大きくなる傾向と類似している.

さび中の $\mathrm{Cl}^{-}$透過の様子を, EPMA 元素分析により

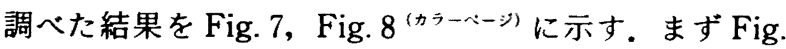
7 は最も付着 $\mathrm{NaCl}$ 量が多い $\left(4.0 \mathrm{~g} \cdot \mathrm{m}^{-2}\right)$ 試験片につ いて, $\mathrm{Cl}^{-}$透過の時間変化を調べたものである. Fig. 7 (a) は試験開始後 1 時間経過したもので，ここではさ び中に $\mathrm{Cl}^{-}$はほとんど見られなかった。しかし 5 時間経 過したときにはFig.7(b)のように，Cl はさび/鋼界面 にまで到達していた，さらに 24 時間経過すると，Fig. 7 (c)のように,さび/鋼界面における $\mathrm{Cl}$ 濃化はさらに顕 著になった。

次に，付着 $\mathrm{NaCl}$ 量が $\mathrm{Cl}^{-}$透過に及ほす影響を $\mathrm{Fig.} 8$ に示す．試験片は塩分付着後， $13^{\circ} \mathrm{C}-\mathrm{RH} 95 \%$ で 24 時間 保持したものである. Fig. 8(a) は付着 $\mathrm{NaCl}$ 量が少な い $\left(0.12 \mathrm{~g} \cdot \mathrm{m}^{-2}\right)$ 場合であり,さび中の $\mathrm{Cl}^{-}$透過はほ とんど見られなかった。このとき溶出した $\mathrm{Fe}^{2+}$ も微量
であった。付着 $\mathrm{NaCl}$ 量が増加すると, Fig. 8(b), Fig. $8(\mathrm{c})$ のようにさび/鋼界面における $\mathrm{Cl}$ 濃化が確認され た.さび/鋼界面にCl が到達した場合, いずれの場合 も, $\mathrm{Cl}$ 濃度はさび表面を除けばさび/鋼界面において最 も高かった. Fig. 6 と Fig. 8 から, 溶出 $\mathrm{Fe}^{2+}$ 量とさび 中の $\mathrm{Cl}^{-}$透過量との間には正の相関があることがわかっ た.

さびを消光部中心の内層（鋼側）と偏光部中心の外層 （大気側）に分けると, 両者における $\mathrm{Cl}$ 濃度分布には大 きな差異が見られた。内層では $\mathrm{Cl}$ 濃度が比較的均一に 分布しており，厚さ方向の濃度勾配は見られなかった。 一方，外層では $\mathrm{Cl}$ 濃度の高い部分がネットワーク状に 分布していた。平均的な $\mathrm{Cl}$ 濃度は内層の方が高かった。 これらの傾向は付着 $\mathrm{NaCl}$ 量が多いほど, 試験時間が長 時間ほど顕著であった。

$\mathrm{Cl}^{-}$に対する長期さびの安定性については, 紀平らが インピーダンス測定を行い, $\mathrm{Cl}^{-}$の存在によりさび層中 の腐食反応に関与する物質の移動が容易になり，アノー ド活性が高まったと報告している2!。また宇佐見らは, 長期に安定化したさびを塩水散布試験及び塩水噴霧試験 に供することにより，一度安定化したさびが生成しても 海塩粒子の多い環境にさらされると, $\mathrm{Cl}$ がさび層界面 にまで到達し，アモルファス相の一部が $\gamma-\mathrm{FeOOH} に$ 変化して,イオン透過抵抗が約 $1 / 10$ に低下して, 安定 さびとしての機能を果たさなくなるものと推定してい る3!.いずれも $\mathrm{Cl}^{-}$によりさびが変質し, 腐食のアノー ド反応により $\mathrm{Fe}^{2+}$ が溶出したと考えられている.

筆者らの実験結果では Fig. 8 から明らかなように, $\mathrm{Cl}$ はさびの非晶質部（内層）に濃化しており，外層の $\mathrm{Cl}$ 濃度は低かった.このことから, 鋼表面のアノード 溶解により電気的中性を満たすために, $\mathrm{Cl}^{-}$が外部から さび/鋼界面近傍に泳動したものと考えられる。

$\mathrm{NaCl}$ 付着による $\mathrm{Fe}^{2+}$ の溶出前後において, $\mathrm{X}$ 線回 折内部標準法により, $\alpha-\mathrm{FeOOH}, \beta-\mathrm{FeOOH}, \gamma-$ $\mathrm{FeOOH}, \mathrm{Fe}_{3} \mathrm{O}_{4}$ を定量した。その結果, Table 2 に示 すように，さび組成の変化は確認されなかった。さらに 偏光顕微鏡観察からも, 非晶質部が存在を維持し, そこ に Cl が濃化していたことがわかった，以上のことから， さびの内層は $\mathrm{Cl}^{-}$に対して透過抑制作用を有していなか ったと推定する。

\section{5 さび中の $\mathrm{Cl}^{-}$透過}

$\mathrm{Cl}$ 濃度分布から,さび中の $\mathrm{Cl}^{-}$透過のメカニズムは 内層と外層とで大きく異なると考えられる，内層はア二 オン選択透過性を有し, $\mathrm{Cl}^{-}$透過がそれに支配されてい ると推測される。

これに対してさびの外層は, 付着 $\mathrm{NaCl}$ 量がある一定

Table 2 Composition of rust on weathering steel before and after laboratory corrosion test (wt\%).

\begin{tabular}{|c|c|c|c|c|c|}
\hline $\begin{array}{c}\text { Deposition } \\
\text { of } \mathrm{NaCl}\end{array}$ & $\alpha-\mathrm{FeOOH}$ & $\beta-\mathrm{FeOOH}$ & $\gamma-\mathrm{FeOOH}$ & $\mathrm{Fe}_{3} \mathrm{O}_{4}$ & Amorphous \\
\hline Before test & 20.1 & 0.0 & 9.0 & 0.9 & 70.0 \\
\hline $0.12 \mathrm{~g} \cdot \mathrm{m}^{-2}$ & 21.3 & 0.0 & 8.2 & 0.0 & 70.5 \\
\hline $4.0 \mathrm{~g} \cdot \mathrm{m}^{-2}$ & 18.3 & 0.0 & 10.5 & 1.4 & 69.8 \\
\hline
\end{tabular}



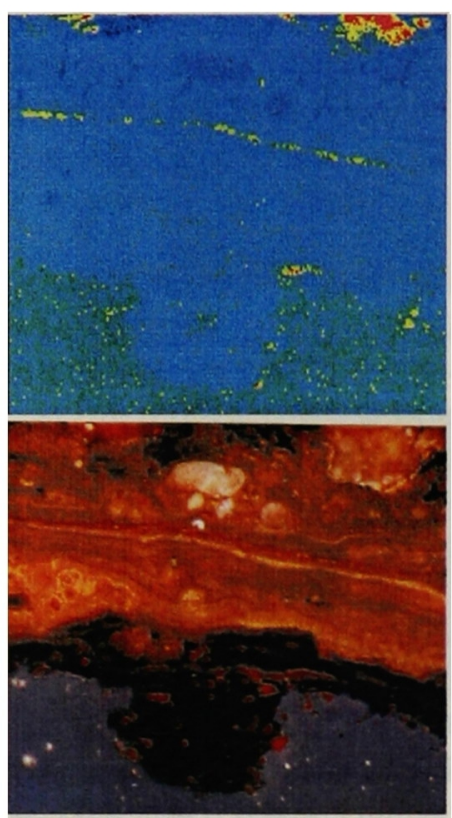

(a ) 1 hour
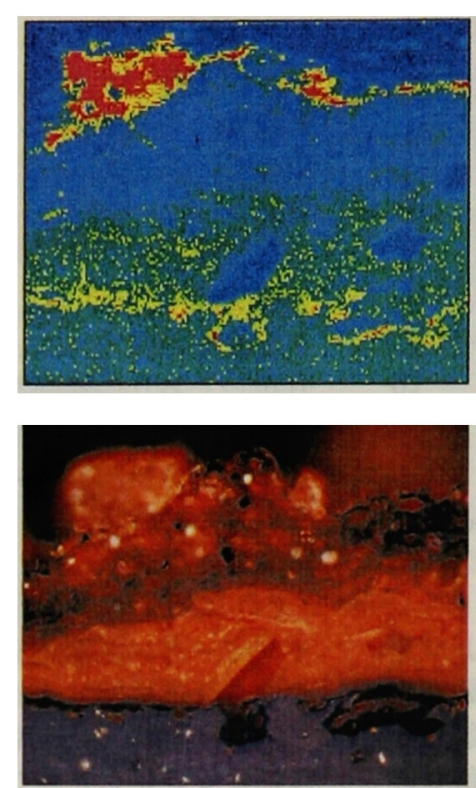

(b) 5 hours
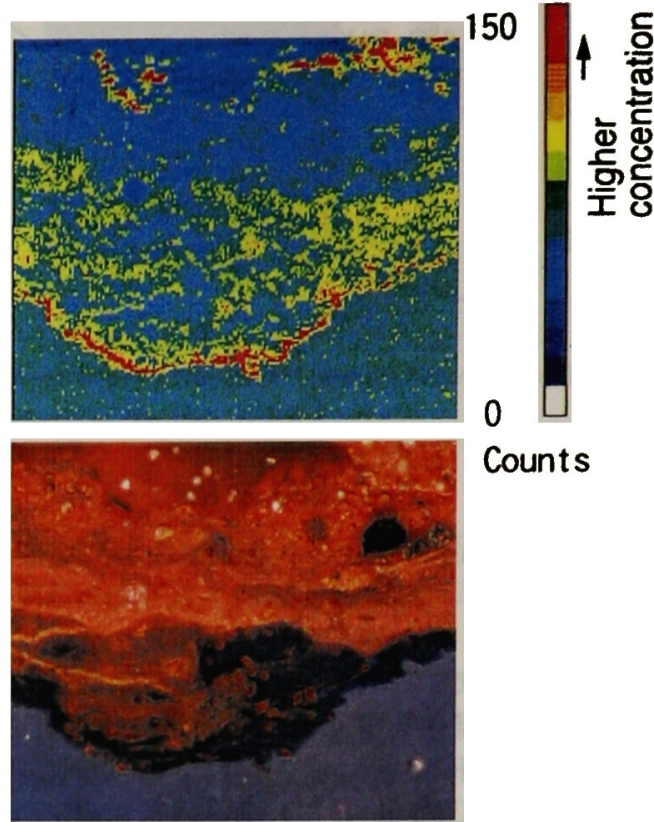

(c) 24 hours

$100 \mu \mathrm{m}$

Fig. 7 EPMA analyses and polarized light image to observe process of chloride penetration through rust formed on 41 year exposed weathering steel. Deposition of $\mathrm{NaCl}: 4.0 \mathrm{~g} \cdot \mathrm{m}^{-2}$.

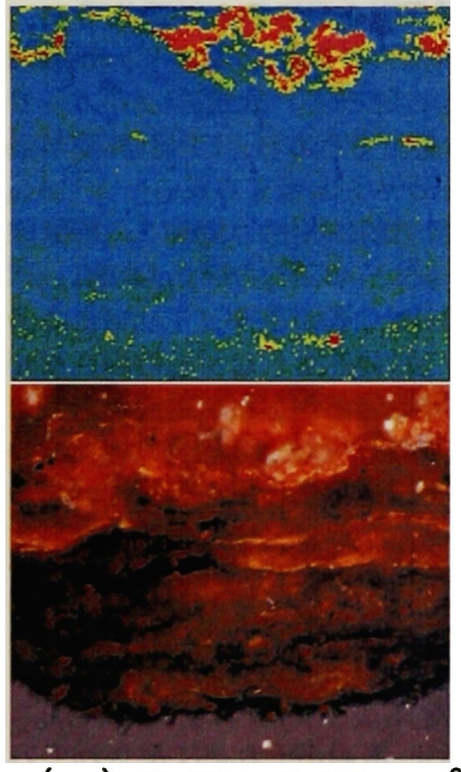

(a) $\mathrm{NaCl}: 0.12 \mathrm{~g} \cdot \mathrm{m}^{-2}$
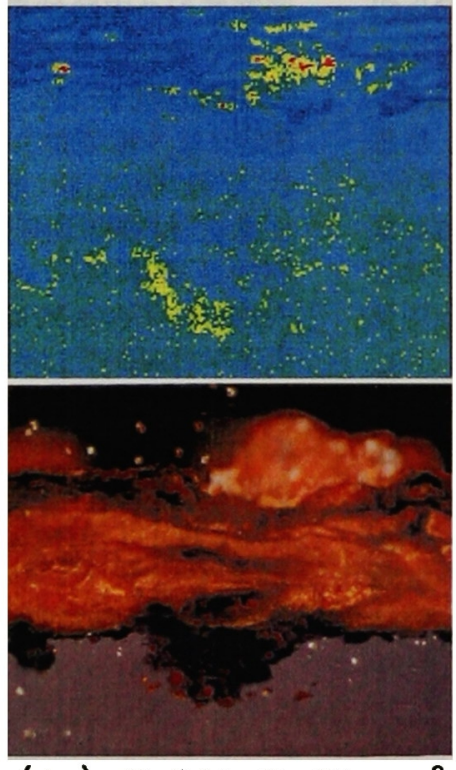

(b) $\mathrm{NaCl}: 0.48 \mathrm{~g} \cdot \mathrm{m}^{-2}$

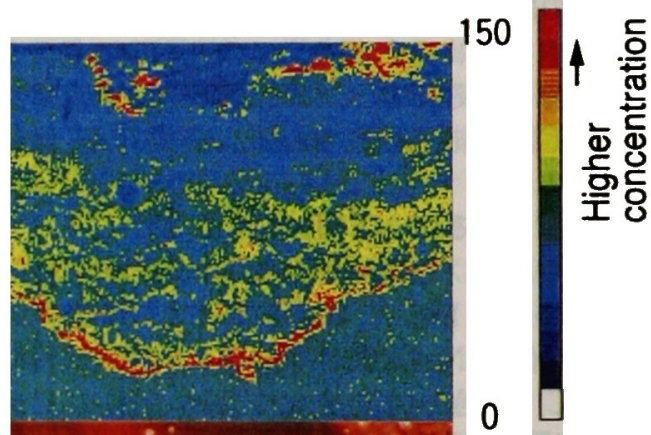

Counts

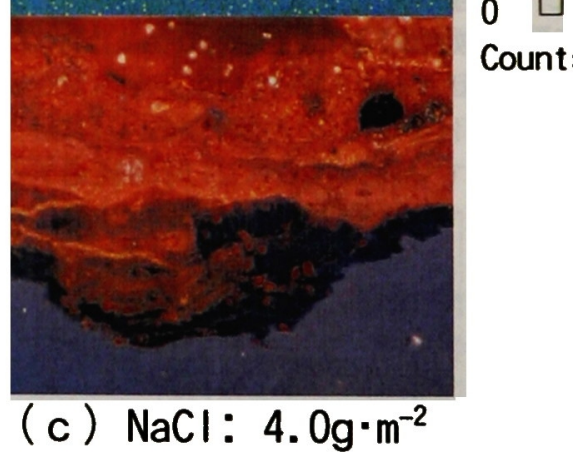

$100 \mu \mathrm{m}$

Fig. 8 EPMA analyses and polarized light images to observe influence of deposition of $\mathrm{NaCl}$ on chloride penetration through rust formed on 41 year exposed weathering steel. Test condition : $13^{\circ} \mathrm{C}-\mathrm{RH} 95 \%, 5$ hours.

量以下のときは $\mathrm{Cl}^{-}$の透過を抑制していた。このことか ら，外層さびはカチオン選択透過性を有している可能性 がある. 一定の付着 $\mathrm{NaCl}$ 量を超えると急激な $\mathrm{Cl}^{-}$の透 過が認められる現象は, このさびのイオン選択透過性が
関連していると考えられる。すすおち固体電荷理論6) 8) によれば, さび細孔内の固定電荷の濃度より細孔内溶液 中の $\mathrm{Cl}^{-}$濃度が高くなると, さびのカチオン選択透過性 は弱まる.このとき, 負の固定電荷の濃度が相対的に小 
さい部分が $\mathrm{Cl}^{-}$透過の経路となりやすいと考えられる. $\mathrm{Cl}^{-}$は選択的にこれらの経路を介して, 内層のアニオン 選択透過性のさび中に達したものと推測される ${ }^{16)}$.

\section{4. 結言}

田園地带に 41 年間暴露した $\mathrm{Cu}-\mathrm{P}$ 添加型耐候性鋼に ついて，付着塩化物に対するさびの保護性および腐食の 再活性化について調へた。 $\mathrm{NaCl}$ を付着させて乾湿繰り 返し試験を行った結果, 新たなさびが点状に発生し，そ の発生量は付着 $\mathrm{NaCl}$ 量に応じて増加した。初期過程で 溶出した $\mathrm{Fe}^{2+}$ の定量により，付着 $\mathrm{NaCl}$ 量がある一定 量を超えると $\mathrm{Fe}^{2+}$ の溶出量は急激に増加することを見 い出した。このとき $\mathrm{Cl}$ はさび/鋼界面に最も濃化してお り, 腐食試験前後でのさびの変質は認められなかった。 したがって $\mathrm{Fe}^{2+}$ の溶出は鋼の $\mathrm{Fe}$ 溶解反応により生じ たものと推測される. 長期に安定化したさびの構造を維 持していても，その保護性は付着塩化物に対して限界を 有していた。

\section{参 考 文 献}

1）建設省土木研究所，陠鋼材俱楽部，陆日本橋梁建设協 会：耐候性鎆材の橋梁への適用に関する共同研究報告書 (XX), (1993).

2）紀平寛，伊藤树，村田朋美 (H. Kihira, S. ITO and T. Murata)：「’84 春季学術講演大会講演予稿集」, p. 308，磨食防食協会 (1984).

3）宇佐見明，田辺康児，井上尚志，增田一広 ( A Usami, K. Tanabe, H. Inoue and K. Masuda)：腐食防
食'92 講演集 (Proc. Fushoku Boshoku '92), p.107, 腐食防食協会（JSCE）（1992）。

4）鈴木一郎, 増子 昇, 久松敬弘 (I. Suzuki, N. Masuko and Y. Hisamatsu)：防食技術 [Boshoku-Gijutsu (Cor. ros. Eng.) ], 20, 319 (1971).

5）鈴木一郎，增子 昇，久松敬弘（I. Suzuki， N. Masuko and Y. Hisamatsu): 防食技術 [Boshoku-Gijutsu (Corros. Eng.)]：防食技術，23，141（1974）.

6）坂下雅雄, 余村吉則, 佐藤教男: 電気化学, 45, 165 (1977)

7）坂下雅雄, 佐藤教男：電気化学，45，238（1977）.

8）余村吉則, 坂下雅雄, 佐藤教男 (Y. Yomura, M. Sakashita and N. Sato): 防食技術 [Boshoku-Gijutsu (Cor ros. Eng.) ], 28, 64 (1979).

9）幸英昭，山下正人，藤原幹男，三澤俊平（H. Miyuki, M. Yamashita, M. Fujiwara and T. Misawa)：材料と 環境 [Zainyo-to-Kankyo (Corros. Eng.)], 47, 186 (1998)。

10）幸 英昭, 山下正人, 藤原幹男, 三澤俊平 (H. Miyuki, M. Yamashita, M. Fujiwara and T. Misawa)：材料と 環境'98 講演集 (Proc. JSCE Materials and Environments 1998)，p.47，腐食防食協会（JSCE）（1998）。

11）玉田明宏（A. Tamada）：防食技術 [Boshoku-Gijutsu (Corros. Eng.)], 27, 309 (1972).

12）武藤 泉, 杉本克久 (I. Muto and K. Sugimoto)：材料と 環境 [Zairyo-to-Kankyo (Corros. Eng.)], 47, 519 (1998).

13）竹村誠洋, 山村知之, 鹿毛 勇, 藤田 栄: 第 19 回防 錆防食技術発表大会講演予稿集, p.63，日本防錆技術協 会 (1999)。

14）岡田秀弥, 細井祐三, 湯川憲一, 内藤浩光：鉄と鋼, 55, 355 (1969).

15）三澤俊平, 山下正人, 松田恭司, 幸 英昭, 長野博夫 : 鉄と鋼，79，69（1993）。

16）松島 蔽, 上野忠之：日本鋼管技報， $41 ， 147$ (1967).

(Manuscript received October 12, 1999 ; in final form December 16, 1999) 